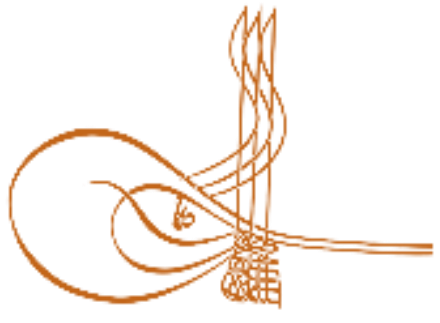

www.turkishstudies.net/social
Turkish Studies - Social Sciences

eISSN: $2667-5617$

Research Article / Araştırma Makalesi

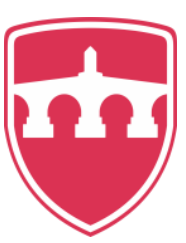

INTERNATIONAL

BALKAN

UNIVERSITY

Sponsored by IBU

\title{
Turizm İşletmelerinde Yabancı Çalışanların Sosyal Destek Algıları Üzerine Keşifsel Bir Araştırma: Sinop Örneği
}

\author{
An Exploratory Research on Social Support Perceptions of Foreign Workers in Tourism \\ Enterprises: the Case of Sinop
}

Kerem Kaptangil* - Kübra Aşan**

\begin{abstract}
With the effect of globalization, migration has become one of the most important events of the modern life. Foreigners started to be seen in the employment markets with the effect of migrations and tourism enterprises became an important field of study for foreign workers. Social support of foreign employees in family, friends and work environment has positive effects on their psychology and performance and facilitates their adaptation with the host community. In this context, the main purpose of the study is to understand the perception of social support in terms of the problems experienced by foreigners working in tourism enterprises in the case of Sinop. For the purpose of the study, in-depth interviews were conducted with migrants and foreign students in Sinop. The collected data were subjected to content analysis. As a result of analysis performed that identified four themes which include the reasons for coming to Turkey, social experiences, study problems and future perceptions. The findings showed that the participants' perception of social support was not low despite problems such as unregistered work, low wages and unqualification. Participants perceived emotional, informational, togetherness and rarely financial support in family, friends and work environments. In addition, the results of the study indicate that the tourism sector is a facilitating and harmonizing field of employment for foreigners, with labor-intensive, seasonal and low-skilled jobs. The study is expected to make original contributions to the literature as it deals with the problem of foreign workers who are subject to very few studies in tourism. As a result of this study, macro recommendations for country policies towards foreign employment and micro recommendations for tourism enterprises employing foreign personnel were tried to be developed.
\end{abstract}

\footnotetext{
* Dr. Öğr. Üyesi, Sinop Üniversitesi, Turizm İşletmeciliği ve Otelcilik Yüksekokulu, Rekreasyon Yönetimi Bölümü Asst. Prof. Dr. Sinop University, Tourism and Hotel Management Academy, Department of Recreation Management ORCID 0000-0002-2319-2661

kerem_kaptangil@hotmail.com

*** Arş. Gör., Sinop Üniversitesi, Turizm İşletmeciliği ve Otelcilik Yüksekokulu, Rekreasyon Yönetimi Bölümü Res. Asst. Sinop University, Tourism and Hotel Management Academy, Department of Recreation Management ORCID 0000-0002-8739-3585

kubra.asan@hotmail.com

Cite as/ Atıf: Kaptangil, K., Aşan, K. (2020). Turizm işletmelerinde yabancı çalışanların sosyal destek algıları üzerine keşifsel bir araştırma: Sinop örneği, Turkish Studies - Social, 15(3), 1203-1221. https://dx.doi.org/10.29228/TurkishStudies.40461

Received/Geliş: 07 January/Ocak 2020

Accepted/Kabul: 25 April/Nisan 2020

Copyright $(C)$ INTAC LTD, Turkey

Checked by plagiarism software

Published/Yayın: 30 April/Nisan 2020

CC BY-NC 4.0
} 
Structured Abstract: Social support refers to the emotional, physical, informative, instrumental and financial assistance provided by people in the environment, which helps people to be cared, to reduce the negative effects of a crisis, a change in their lives, and to protect their psychological health. Social support, which has positive effects in terms of human psychology, has effects on foreign workers such as reducing stress and increasing productivity (Kovacev ve Shute, 2004; Simich, Beiser, Stewart, 2005; Goda, Savolainen, 2017). However, empirical studies on the perception of social support of foreign workers in the tourism sector are not common in the literature. From this point of view, exploratory approach was followed in order to provide deep information on the subject. A field study was conducted in the Sinop sample by applying the interview technique which is one of the qualitative research methods. The study is expected to make some contributions on macro and micro scale. Determining the level of social support perceived by foreign workers in their workplaces in a different country where they are trying to be on equal terms is important for foreign workers as well as other elements in which they interact.

Social support of foreign employees in family and work environment has positive effects on their psychology and performance and facilitates their adaptation with the host community. In this context, the main purpose of the study is to understand the perception of social support in terms of the problems experienced by foreigners working in tourism enterprises in the case of Sinop. For the purpose of the study, in-depth interviews were conducted with migrants and foreign students in Sinop. The collected data were subjected to content analysis. As a result of analysis performed that identified four themes which include the reasons for coming to Turkey, social experiences, study problems and future perceptions.

The concept of social support, which is highly influenced by the perceptual variable, is inevitable when there is an inconsistency that occurs when people's perception and judgment about the adequacy of social support does not match their social support situations. Therefore, scientific studies on social support have been made quantitatively, but subjective evaluation of possible conflicts between the current situation and the perceived situation has produced different results in the researches. Perceptual social support studies conducted in order to reveal this difference provide guidance in terms of revealing psychological elements (Coyne ve Downey, 1991; Çakır ve Palabıyıkoğlu, 1993; Gökler, 2007; Schweitzer vd., 2006; Ünüvar, 2003).

It has been found that the effects of social support, which is the subject of the research subject, have a higher degree of effect on perceptions of various traumas and psychological problems. The reason for the research is that foreign employees have high uncertainties and future concerns, and the idea of continuing to live at risk as a result of the stress caused by the adaptation process to new life and cultures is at high levels. The fact that the social support element that directs individual psychology affects many social dynamics has revealed the necessity of conducting the research in a way different from previous studies.

The study, which was applied in the case of Sinop for the purpose of examining the problems experienced by foreigners working in tourism sector and their perceptions of social support, showed that although the foreign workers experienced a series of working problems, their perceptions of social support were not low levels. Identified themes within the framework of working life and their presence in Turkey, the findings were positive for the continuation of a perceptual process. Due to the disadvantage of foreigners, foreign workers are employed at a lower wage compared to normal conditions. In addition, employees are forced to work informally and without social security as obtaining a work permit for employers is a cost item. On the other hand, this situation is regarded as also lack of inspection due to the operation of the port to employ workers in this case unlawful encouraging elements are met as a natural process due to experiencing fluctuating employment policies in the life of economic conditions and working that are located in Turkey.

In addition to the problems related to working life, it was noted in the social experiences that the foreigners experienced negative conditions regarding the social acceptance. However, when they compare this complex situation with their own country, they are acceptable and can also see it temporarily. As a result of this situation, they perceive their current situation as a temporary process and they see this process as bearable.

As a result of the information obtained, the most important result of the study is that the perception of social support of foreign employees is relatively high compared to their problems. In fact, this situation highlights the difference between social support and perception of social support. Perception variable affects the adequacy of social support. In the study, they were asked to conduct a subjective assessment by directly contacting foreign employees and it was determined that the employees considered the current social support sufficient by taking an acceptive approach with the effects of their past experiences. 
Although the employees differ according to the related environment, it is understood that they mostly receive emotional support. Emotional, togetherness and knowledge support from their private environment; On the other hand, foreign employees who receive emotional and information support from the working environment can rarely receive financial support from all their environments. At this point, the socio-cultural structure of Turkey in the selection of people to live or work and have a positive impact on previously acquired knowledge lack of compliance is acceptable. Tourism has labor-intensive, seasonal and low-skilled jobs, thus facilitating employment for foreigners to find jobs. Especially foreigners who can learn Turkish can easily find a place in tourism sector which is open to different cultures. However, the findings indicate that the participants are unable to plan in the long term and are in a state of uncertainty due to the legal situation. In this context, as Baum (2012) states, the approach of foreign employees in the tourism sector to make short-term plans and to see tourism temporarily supports the approach. On the other hand, in economies that determine tourism as an important part of development in terms of national income, quality is an indispensable element of continuity in addition to long-term strategic personnel planning, reveals the necessity of more sensitive and legal treatment of foreign employees.

Keywords: Foreign Workers, Social Support, Tourism Enterprises, Refugees, Foreign Students

Öz: Göç, küreselleşmenin etkisiyle modern dünyanın en önemli olaylarından biri haline gelmiştir. Göçle birlikte istihdam piyasalarında yabancılar görülmeye başlamış, turizm işletmeleri de yabancılar için önemli bir çalışma alanı olmuştur. Yabancı çalışanların aile, arkadaş ve iş ortamında sosyal destek görmeleri psikolojileri ve performansları üzerinde olumlu etkiler yaratmakta ve ev sahibi toplumla uyum yaşamalarını kolaylaştırmaktadır. Bu bağlamda çalışmanın temel amacı, Sinop örneğinde turizm işletmelerinde çalışan yabancıların yaşadıkları sorunlar açısından sosyal destek algılarının anlaşılmasıdır. Çalışmanın amacı doğrultusunda Sinop’ta mülteci ve yabancı öğrenciler ile derinlemesine görüşmeler gerçekleştirilmiştir. Toplanan veriler içerik analizine tabi tutulmuştur. Yapılan analiz sonucunda, katılımcıların Türkiye'ye geliş nedenleri, burada edindikleri sosyal deneyimler, yaşadıkları çalışma sorunları ve gelecek algıları olmak üzere dört temaya ulaşılmıştır. Bulgular katılımcıların kayıtdışı çalışma, düşük ücret, niteliksizleştirme gibi sorunlara rağmen sosyal destek algılarının düşük olmadığını göstermiştir. Katılımcıların aile, arkadaş ve iş ortamlarında duygusal, bilgisel, beraberlik ve nadiren de maddi destek algıladıkları görülmüştür. Ayrıca çalışmanın sonuçları emek yoğun, mevsimsellik ve düşük vasıf gerektiren işleri de içinde bulunduran geniş iş ölçeği özellikleriyle turizm sektörünün, yabancıların istihdamı için kolaylaştırıcı ve uyumlaştırıcı bir iş alanı olduğunu işaret etmektedir. Çalışmanın, turizmde oldukça az çalışmaya konu olan yabancı çalışanlar sorununu ele aldığından alan yazına özgün katkılar sağlaması beklenmektedir. Çalışmanın sonucunda yabancı istihdamına ve ülke politikalarına yönelik makro ve yabancı personel çalıştıran turizm işletmelerine yönelik mikro öneriler geliştirilmeye çalışılmıştır.

Anahtar Kelimeler: Yabancı Çalışanlar, Sosyal Destek, Turizm İşletmeleri, Mülteciler, Yabancı Öğrenciler

\section{Giriş}

İnsanların birlikte yaşama arzusundan ortaya çıkan sosyal toplum anlayışı günümüzde birçok sebepten değişiklik göstererek insanların kendi kültür ve toplumlarından ayıracak unsurlara dönüşmektedir. Bu unsurların neticesinde ortaya çıkan anlayışlardan birisi de göç kavramıdır. Tarih boyunca çok kez görülen göç konusu, küreselleşmenin etkisiyle modern dünyanın en önemli olaylarından biri haline gelmiştir. İşsizlik, savaş, din ve terör baskısından kaçmanın yanı sıra daha iyi eğitim, yeni iş, farklı kültürleri tanıma amaçlarıyla insanlar yer değiştirmektedir. Türkiye, göç açısından oldukça yoğun bir ülkedir (Kara ve Korkut, 2010). Türkiye'nin sunduğu emek piyasası koşulları ve sosyal haklar, Batı Avrupa ülkelerindeki kadar gelişmiş olmamasına rağmen, coğrafi konumundan dolayı Türkiye yıllardır göç için cazip bir ülke olarak görülmektedir (Demir, 2016). Birleşmiş Milletler'e bağlı Ekonomik ve Sosyal İşler Organizasyonu'nun (DESA) yayınladığı 2019 göç raporuna göre Türkiye'de 5 milyon 678 bin 800 mülteci ve göçmen bulunmaktadır.

Yabancıların Türkiye’deki işgücü piyasalarına katılımı 1990’lı yıllardan itibaren görünür olmaya başlamıştır (Lordoglu, 2007). Emek yoğun özelliğiyle turizm, yabancıların çalıştığı öne çıkan sektörlerden biri olmuştur (Gökmen, 2015; Lordoglu, 2007). Dünya'nın pek çok bölgesinde 
konaklama endüstrisi temsilcilerinin, operasyonel boyutta yabancı işçilerin sektör için hayati bir öneme sahip olduğu ve gelecekte de bu önemin artacağı konusunda hem fikir olduğu görülmektedir (Baum, 2012). Dolayısıyla yabancı çalışanlar turizm sektörü için önemli ve yönetilmesi gereken bir iş gücü kaynağıdır. Ancak yabancıların kayıtdışı istihdam, sosyal güvenlik, niteliksizleştirme gibi konular başta olmak üzere pek çok sorunu olduğu görülmektedir (Demir, 2016; Lordoglu, 2007; Gökmen, 2015). Öte yandan turizm kapsamında yabancı çalışanlar üzerine oldukça az sayıda akademik çalışma yapılmıştır. Özellikle ulusal ölçekte yabancı çalışanlar konusunda araştırma yok denecek kadar azdır. Çalışmada bu boşluğa hitaben turizmde yabancı çalışanlar konusu incelenmektedir. Çalışmanın odaklandığı problem ise yaşadıkları sorunlar paralelinde turizmde çalışan yabancıların sosyal destek algılarının anlaşılmasıdır.

Sosyal destek, insanların önemsendiğine, yaşamlarındaki bir krizin, bir değişikliğin olumsuz etkilerini azaltabilmelerine ve psikolojik sağlıklarının korunmasına yardımcı olan, çevredeki insanlar tarafindan sağlanan duygusal, fiziksel, bilgilendirici, araçsal ve parasal yardımı ifade etmektedir (Meral ve Cavkaytar, 2012). İnsan psikolojisi bakımından olumlu etkileri olan sosyal desteğin yabancı çalışanlar üzerinde stresi azaltma, verimliliği artırma gibi etkileri vardır (Kovacev ve Shute, 2004; Simich, Beiser, Stewart, 2005; Goda, Savolainen, 2017). Ancak literatürde turizm sektörü temelinde yabancı çalışanların sosyal destek algılarına yönelik ampirik çalışmalar sınırlıdır. Buradan hareketle çalışmada konuyla ilgili derin bilgiler sağlamak üzere keşifsel yaklaşım izlenmiştir. Nitel araştırma yöntemlerinden görüşme tekniğine başvurularak Sinop örneğinde bir saha çalışması gerçekleştirilmiştir.

Çalışmanın makro ve mikro ölçekte birtakım katkılar sunması beklenmektedir. İlk olarak, yabancı çalışanların eşit şartlarda olmaya çalıştıkları farklı bir ülkedeki çalışma alanlarında algıladıkları sosyal destek düzeylerinin belirlenmesi, yabancı çalışanların çalışma hayatında olduğu kadar aynı zamanda etkileşim içinde bulundukları diğer unsurlar için de önem arz etmektedir. Algılanan sosyal destek noktası ülkedeki yabancı çalışanların mevcut ve gelecekteki istihdam içindeki yoğunluklarını, verimliliklerini ve toplumsal sosyo-ekonomik dengeleri etkileyeceği düşünüldüğünde ülkelerin istihdam ve para politikalarına da etkileri her geçen gün değişkenlik gösterebilecektir. $\mathrm{Bu}$ nedenle gelişmiş ülkelerin gerek politik gerek siyasal gerekse ekonomik stratejilerini oluştururken genel olarak kayıtdışı olarak karşımıza çıkan bu ciddi iş gücü potansiyelinin incelenerek bir uzgörü stratejisi hazırlanmalıdır. Ancak devletlerin istatistiksel olarak rakamlar üzerinden ya da farklı hesaplamalarla belirledikleri stratejik planlar çoğu zaman kayıt altına alınamayan değişkenler nedeni ile planlananla gerçekleşen arasında ciddi farklar ortaya çıkarabilmektedir. $\mathrm{Bu}$ nedenle zaten kayıtdışı çalışarak belirli ekonomik yükümlülüklerden kaçınmaya çalışan gelişmekte olan ülke ekonomilerindeki işletmelere ve çalışanlara yönelik elde edilecek her türlü bilgi, gelecekteki stratejilerin doğru olarak belirlenmesi noktasında önem taşımaktadır. Ayrıca çalışmanın çıtılarının mikro ölçekte turizm işverenleri için yabancı işgücünün yönetilmesi konusunda katkı sağlaması hedeflenmektedir.

\section{Yabancıların Hukuki Durumları ve Turizmde İstihdamları}

Göç kavramı temelde insanların fiziki olarak yer değiştirmesi olarak kabul görmekle birlikte bu kavram içerisinde barındırdığı bileşenler sebebiyle çok daha derin etki alanına sahiptir. Göç, kişilerin yaşamakta oldukları bölgelerden, ekonomik durumlarından, oluşturdukları sosyal yapılanmalarından, kültürlerinden ve toplumsal yaşamın pek çok bileşeninden koparak veya kopartılarak yeni yerlere yerleşmesi ve yeniden bir yaşam kurması demektir (Toros, 2008). Bu noktada kişilerin yer değiştirmesi olarak algılanan göç kavramının gerek terk edilen toplumları gerekse yeni yerleşilen topraklardaki toplumları etkileme dereceleri göz önüne alındığında bu durumun sadece bir yerleşim yeri değiştirmeden çok daha önemli değişkenleri içerdiği gözlemlenmektedir. Göç ile birlikte ortaya çıkacak olan değişimler en çok psikoloji, eğitim, ekonomi, tarih, hukuk, uluslararası ilişkiler gibi alanlarda kendini göstermektedir. Ancak bu noktada 
önemli bir diğer nokta topraklarından ayrılarak başka yerlere göç eden kişilerin bu davranışlarındaki sebebinin belirlenmesidir. Çünkü bu yer değiştirme sebeplerine göre hukuki açıdan göçmen, mülteci ya da sığınmacı olarak adlandırılabilmektedir.

Bu kavramlar arasındaki ilişkiler incelendiğinde göçmenlikle ilgili olarak; "kişisel rahatlık amacıyla ve dışarıdan herhangi bir zorlama unsuru olmaksızın ilgili kişinin hür iradesiyle göç etmeye karar verdiği durumları kapsadığı” kabul edilmektedir. Dolayısıyla bu terim, hem maddi ve sosyal durumlarını iyileştirmek hem de kendileri ve ailelerinin gelecekten beklentilerini arttırmak için başka bir ülkeye veya bölgeye göç eden kişi ve aile fertlerini kapsamaktadır" (Uluslararası Göç Örgütü, 2009). Mülteci ise; "1rk1, dini, tabiiyeti, belirli bir sosyal gruba mensubiyeti ve siyasi görüşleri yüzünden haklı bir zulüm korkusu nedeniyle vatandaşı olduğu ülkenin dışında bulunan ve söz konusu korku yüzünden ilgili ülkenin korumasından yararlanmak istemeyen kişidir” şeklindedir. Sığınmacı ise "ilgili ulusal ya da uluslararası belgeler çerçevesinde bir ülkeye mülteci olarak kabul edilmek isteyen ve mültecilik statüsüne ilişkin yaptıkları başvurunun sonucunu bekleyen kişilerdir. Olumsuz bir karar çıkması sonucunda bu kişiler ülkeyi terk etmek zorundadırlar ve eğer kendilerine insani ya da diğer gerekçeler nedeniyle ülkede kalma izni verilmemişse bu kişiler ülkede düzensiz bir durumda bulunan herhangi bir yabancı gibi sınır dışı edilebilirler" şeklinde tanımlanmaktadır (Uluslararası Göç Örgütü, 2009).

Turizm sektörü yabancı çalışanların istihdam sağladığı öne çıkan sektörler arasındadır. Benzer şekilde çalışma izni olmadan çalışan yabancıların bulunduğu sektörler içinde de konaklama ve eğlence hizmetini kapsayan turizm öne çıkmaktadır (Demir, 2016; Lordoğlu, 2007). Türk Hukukuna göre, bir yabancının kendisine yasaklanmamış alanlarda, iş sözleşmesi ehliyetine sahip olabilmesi için, çalışma izin belgesi bulunmalı veya bundan muaf tutulmuş olmalı ve yabancı uyruklu işçi çalıştıran işverenlerin çalışma izin belgesindeki izin başlangıç tarihinden itibaren 30 gün içinde sigortalı işe giriş bildirgesi düzenleyerek Sosyal Güvenlik Kurumu'na vermeleri gerekmektedir (Demir, 2016). Bu işlemler yapılmadığında çalışanlar kayıtdışı olarak çalıştırılmaktadır. Göçmenlerin içinde bulundukları olumsuzluklardan ötürü güvencesiz çalışma biçimlerine ve olumsuz çalışma koşullarına yerli işçilere oranla daha fazla katlanması gerekmektedir (Gökmen, 2011). Dahası benzer sebeplerden ötürü yabancıların düşük ücretle çalışmaya razı oldukları görülmektedir (Araslı, Arıcı ve Ilgen, 2019). Bu durum işverenler için ucuz ve yedek işgücü kaynağı yaratmaktadır. Sonuç olarak yabancılar düşük ücret ve sosyal güvence olmaksızın çalışmak durumunda kalabilmektedir. Turizmde yabancı göçmen kadınların istihdam koşullarını incelediği çalışmasında Gökmen (2011) göçmen kadınların ücretlerinin eksik ödenmesi, zamanında ödenmemesi, fiziksel ve sözlü tacize uğrama, elverişsiz koşullarda güvencesiz olarak çalıştırılma gibi sorunlara ek olarak niteliksizleştirme sorunu yaşadıklarını ortaya koymuştur. Buna göre kadınların kendi ülkelerinde almış oldukları eğitimden ve sahip oldukları niteliklerden bağımsız olarak söz konusu işlerde çalıştırılmaları niteliksizleşmelerine neden olmaktadır.

Sorunlara rağmen turizm sektörü pek çok yabanc1 için özellikle vasıf düzeyi düşük işlerde kolayca istihdam sağlayabilmektedir. Baum'un (2012) Uluslararası Otel Endüstrisi Göçmen İşçi raporunda belirttiği üzere turizm sektörü farklı kültürlere karşı iletişime daha açık bir sektördür. Aynı raporda çalışanların turizmde uzun vadeli bir kariyer taahhüdü olmadığı, turizmin başka sektörlere geçiş ya da kendi ülkelerine dönme hedeflerinde orta ila uzun vadeli bir amaç olarak kaldığ 1 görülmektedir. Sonuç olarak sektör için yabancı çalışanlar bir iş gücü kaynağı iken; çalışanlar için de turizm kolayca istihdam sağladıkları bir sektördür.

\section{Sosyal Destek Kavramı}

Günümüzde toplum içerisinde yaşayan insanların gerek çalışma hayatlarında gerekse sosyal yaşamlarında başarıya ulaşmaları, sosyal desteğin bireyi hem fizyolojik hem de psikolojik olarak etkileme derecesine bağlıdır (Thoits, 1995: 65; Uchino ve Garvey, 1997: 21). Ancak son y1llarda araştırmalara konu olmuş bu kavrama yönelik farklı yaklaşımlar olması sebebiyle tam olarak bir 
tanımın yapılması oldukça güçleşmiştir (Zimet, 1988:30). Bunun temel nedeni ise; kavramın çıkış noktasının psikolojik bir unsur olmasından kaynaklı olarak savunulan durumun kişinin yalnızca kendisinden kaynaklanabilecek, kendi düşünce sistemleri ile ilgili olabilecek sorunları olduğu gibi, etrafındaki kişilerin etkisiyle de biçimlenen davranış, düşünce ve duyguların çok yönlülüğüne bağlı olarak sosyal desteğin tanımlanmasının ve ölçülmesinin güç olmasıdır (Hupcey, 1998). Sosyal destek kavramının temeli Durkheim'ın (1897) kişiler arasındaki sosyal desteğin varlığına ve hayattaki önemine dair yapmış olduğu çalışmalarla atılmıştır. "İntihar" isimli çalışmasında kişiler arasındaki sosyal bağların ve sosyal desteğin intihar olayları ile ilişkisini araştıran Durkheim, sosyal bağları güçlü olmayan bireylerde intihar olaylarının daha fazla görüldügü sonucunu ortaya koymuştur. $\mathrm{Bu}$ çalışma, dönemin sosyal bilimcilerinde kişiler arası yakın sosyal ilişkilerin önemine ilişkin düşüncelerin oluşmasına ve ortaya konmasına sebep olmuş ve günümüze kadar birçok araştırmacıya farklı yaklaşımlarla konu olmuştur. Kuramın teorik temelleri ise Kurt Lewin "Alan Kuramı" yaklaşımı ile atılmıştır (Boldwin, 1967). Lewin, davranışların tanımını yaparken davranışın ruhsal çevrede oluşan değişimler sonucu olduğunu ve bu çevrenin bütün etmenlerinin kişinin davranış tutumlarında etkili olduğunu ifade etmektedir. Buna göre eğer birey istenmeyen davranışlarından kurtularak olumlu davranış kazanımları sağlamak istiyorsa, davranışı etkileyen temel etken olan çevresinde değişiklikler yapması gerektiği belirtilmektedir. İşte bu noktada değiştirilmesi düşünülen bireyin çevresel unsurları ve sosyal destek ağı bu çevre içerisinde bulunmaktadır (Akt. Yıldırım, 1998, s.33).

Sosyal destek kavramı Caplan (1974), Cobb (1976) ve Cassel (1976) tarafindan ortaya konulan araştırmalarla ilerletilmiştir. Cobb'a (1976) göre bir bilgilenme çeşidi olan sosyal destek, insana içinde bulunduğu sosyal gruba aidiyet, sevilme ve saygı duyulma duygularını yaşatmaktadır. Caplan (1974) ihtiyaç duyulduğu anlarda sosyal desteğin, kullanılan araçlara bağlı olarak ya da bilgisel önderlik sağlayıcı olduğunu savunmaktadır. Cassel (1976) ise sosyal desteğin kişiyi stres veren olumsuz yaşamsal durumlara karşı koruyucu bir işlevi olduğunu belirtmektedir. Barrera, Sandler ve Ramsay (1981) sosyal desteği kişinin ihtiyaç duyduğunda kendisine yardımcı olan insanların sayısıyla açıklarken, Sorias (1988) kişi için aile üyeleri, arkadaş çevresi, komşular, meslektaşlar gibi kişinin hayatında değeri olan insanlarca gerçekleştirilen işlevler olarak açıklamaktadır. Bir diğer yaklaşıma göre; hayatta olduğumuz süre içerisinde, hayata dair başımıza gelen birçok durumda, bireye bu durumlar karşısında yardım eden ve ona destek olan tüm insanlar arası ilişkilere sosyal destek denmektedir (Stromborg ve Olsen, 1997; Hurdle, 2001). Kapsam olarak biraz daha genişletilmiş bir tanıma göre; "kişilerin sevildiğine, değer verildiğine, önemsendiğine, yaşamındaki bir krizin, bir değişikliğin olumsuz etkilerini azaltabilmesine ve yaşamındaki kritik durumlara uyumunun kolaylaşabilmesine ve psikolojik sağlığının korunmasına yardımcı olan, çevresindeki insanlar tarafından sağlanan duygusal, fiziksel, bilgilendirici, araçsal ve parasal yardım olarak" tanımlanmaktadır (Meral ve Cavkaytar, 2012: 20).

Alan yazındaki birçok yaklaşım ve tanıma göre belirlenen temalara göre sosyal destek Terzi'ye göre (2016) 3 ayrı şekilde ortaya çıkarılırken Caplan (1974), sosyal desteğe farklı boyutların eklenmesiyle 5 farklı unsur şeklinde gerçekleştiğini savunmuştur. Bu unsurlardan duygusal destek; desteğin temelini karşılıklı sevgi, güven, ilgi gibi temel duyguların oluşturduğu ve aynı zamanda kişilerin bir sorunu olduğu zaman bu sorunlarını paylaşabildiği, özel hayatına ilişkin konuları konuşup rahatladığı hayatındaki özel ve önemli kişilerle ortaya koyduğu iletişimsel desteği ortaya çıkartmaktadır (Kaner, 2002). Takdir desteği; bireyin iş ortamında ya da gündelik hayatta yapmış olduğu doğru ya da yanlış eylemlere saygı duyulmasını ifade eder. Bu durum kişinin çalışma ortamında yapmış olduğu faaliyetlerin fark edildiği, çalışmalarının karşılığı olarak üstler tarafından onaylandığı ve takdir edildiği anlamına gelmektedir (Richman ve Rosenfeld, 1988). Maddi (araçsal) Destek; kişilerin ilişki içerisinde oldukları örgüt tarafindan sağlamakta oldukları maddi yardımı, araç gereç yardımı, gerekli olan materyal kaynağı gibi somut yardımları kapsayan sosyal destek türüdür (Cohen ve Wills, 1985, s.321). Bilgisel destek; kişiye karşılaştığı sorunları çözebilmesi için sunulan 
bilgi desteğini ifade eder. Kişiye verilen bu destek sorunları çözmesine yardımcı olmanın yanında bilginin nasıl doğru kullanılacağına dair bilgileri de içerir (Caplan, 1974). Ve son olarak beraberlik desteği ise; kişilerin çalışma hayatı dışında kalan boş vakitlerini çevresindeki diğer insanlarla geçirmesini, onlarla beraber sosyalleşebilmesini, eğlenebilmesini ve pozitif düşünerek beraber olduğu gruba aidiyet hissedebilmesini ifade etmektedir (Caplan, 1974).

Sosyal desteğin birçok tanımının olması ve aynı zamanda birçok bileşenden oluşmasının yanında sosyal destek kavramı genel olarak iki nokta üzerinde yoğunlaşmıştır. Bunlardan birincisi stres kaynakları ile baş etmek için yardım istenebilecek insanların varlı̆̆ı, ikincisi ise kişilerin var olan yardımları algılama biçimleri ve memnuniyet dereceleridir (Kurt, 2019). Bu noktada ortaya çıkan farklı bir unsur olan sosyal desteğin algılanabilme derecesi de önemli hale gelmektedir. Ancak bu durumda da algılanan desteğin nasıl algılandığ 1 ve hangi unsurlarla ilişkilendirileceği önem taşımaktadır (Bruhnn ve Philips, 2011). Kişinin kendi öz benliği ve algılamış olduğu sosyal desteğin beraber ortaya çıkması kişinin gerek sosyal gerekse iş hayatında daha cesaretli davranmasını da sağlamaktadır. $\mathrm{Bu}$ unsurlara bağlı olarak sosyal destek kavramının, algılanan sosyal destek kavramından ayrı düşünülmesi gerekliliği ortaya çıkmıştır (Sarason, 1983).

Alg1, kişilerin eğitim, çevre, yer, zaman ve psikolojik durumların değişkenliğine bağlı olarak farklılaşabilen bir unsurdur. Dışardan gelen bir desteğin ne şekilde etkide bulunacağ 1 ise o desteğin algılanma derecesine göre de değişebilmektedir (Sarason, 1985). Buna bağlı olarak da algılanan sosyal destek, bireyin çevresinde yaşadığ 1 olaylar üzerinde dururken algılanan sosyal destek algıs1 ise bireyin ruh sağlığı ile alakalıdır (Sarason ve Pierce, 1985). Algılanan sosyal destek derecesi noktasında bir diğer görüşe göre ihtiyaç duyulan andaki desteğe olan inanç ve desteğe olan güven algının yanında davranışsal deneyimlerle de ilişkilendirilmiştir (Reinhardt ve Boerner, 2006). Davranışsal bu deneyimler kişilerin farklı algısal boyutları ile şekillendiğinde iyi niyetli olarak verilen sosyal desteği başarısız gösterebilmekte, destek çabaları boşa çıkabilir ya da desteklenen kişinin durumu daha kötü bir hal alabilmektedir. Buradaki kilit nokta sosyal desteğe ihtiyacı olan kişinin ruhsal derinliğinin ve hislerindeki ruhsal boyutun farklı olabilmesidir. Çünkü sosyal desteğin algılanma şekli cesaretlendirici olabilmesinin yanında aynı zamanda yargılayıcı olarak da algılanabilmektedir. Kişiler sosyal desteği daha fazla stres yaratabileceği ihtimali ya da psikolojik olarak negatif bir durumu irdeleyerek daha fazla zarar göreceklerine inanırlarsa kaçınma yolunu da seçebileceklerdir (Coyne ve Ellard, 1990).

Sosyal destekle ilgili olarak kişilerin yaşamış oldukları olaylara karşı göstermiş oldukları direnç ve sosyal desteğe duydukları güven duygusu, içinde bulundukları sosyal ağ ile yakından ilgilidir. Sosyal ağ olarak açıklanmaya çalışılan durum insanların hayatlarında yer alan, destek için başvurulan iş ve sosyal çevredeki ilişkileri temsil etmektedir (Sorias, 1988). Kişinin ihtiyaç duyduğu ve bireye bilişsel aynı zamanda da duygusal destek veren ilişkiler, kişinin psikolojik ve fiziksel sağlığını koruyucu bir etki içerirler (Taysi, 2000). Thoits'e (1982) göre, kişilerin sosyal ağlarının olması yaşantısına anlam katarak sağlıklı bir psikolojik yapı ve pozitif davranış kalıplarına sahip olmasını sağlamaktadır. Farklı sosyal ağlar içerisinde sevilen ve değerli görülen kişiler kendilerini mutlu ve güvende hissederler, tersi durumlarda ise psikolojik rahatsızlıklara ortam hazırlayan kayg1 ve değersiz hissedilme duygularına kapılacaklardır. Bu durumda da sağlıkla ilgili sorunlar ortaya çıarak kişilerin yaşama sürelerini etkileyecek ya da çok sık rastlanan durumlarda olduğu gibi farklı kişilik yapıları ortaya çıkacaktır (Cohen ve Janicki, 2009).

Algısal değişkenin yüksek oranda etkilediği sosyal destek kavramı, sosyal desteğin yeterliliğine dair kişilerin kendi algı ve yargısı ile gerçekleşen sosyal destek durumları örtüşmediği zamanlarda ortaya çıkan bir tutarsızlık durumu ise kaçınılmazdır. Bu nedenle yapılan bilimsel çalışmalar, sosyal destekle ilgili olarak nicel olarak yapılmış, ancak mevcut durumla algılanan durum arasında muhtemel çakışmaların öznel olarak değerlendirilmesi, araştırmalarda farklı sonuçlar ortaya çıkartmıştır. Bu farklılığı ortaya koymak amacıyla yapılan algısal sosyal destek çalışmaları psikolojik 
unsurları ortaya koyması açısından yol gösterici olmaktadır (Coyne ve Downey, 1991; Çakır ve Palabıyıkoğlu, 1993; Gökler, 2007; Schweitzer vd., 2006; Ünüvar, 2003).

Yabancı çalışanlar noktasında incelenmiş algılanan sosyal destek kavramı, farklı ülkelerde yaşama ve çalışma durumunda kalan bireylerin destek gördükleri sosyal alanları oluşturan aile, akrabalar, çalışma arkadaşları, içerisinde bulunulan sosyo-kültürel ortamın değişmesi kişiler üzerinde farklı etkiler yaratabilmektedir. Aynı zamanda bu etkenlerde oluşan destek değişikliği ya da sosyal destek kaybı kişiler üzerinde ciddi psikolojik etkilere sebep olabilmektedir (Yıldırım, 1997). Araştırma konusunu oluşturan sosyal desteğin etkilerinin kişilerde oluşan çeşitli travmalar ve psikolojik sorunların algıları etkileme noktasının çok daha yüksek olduğu; belirsizlikler ve gelecek kaygılarının fazla olduğu, yeni yaşam ve kültürlere uyum sağlama süreçlerinin ortaya çıkarttığ 1 stres ve savunmasızlık psikolojisi ve sonucunda ortaya çıkan risk altında yaşama devam etme düşüncesinin etkilerinin önemli oluşu araştırmanın yabancı çalışanlar üzerinde yapılabileceğini göstermiştir. Bireysel psikolojiyi etkileyen sosyal destek unsurunun makro açıdan toplumsal birçok dinamiği etkilediği düşünüldüğünde daha önce yapılmış çalışmalara farklı bir yöntemle yaklaşılması araştırmanın çıkış noktasını desteklemektedir.

Doğrudan turizm sektörüyle ilgili olmamakla birlikte daha önce yapılan çalışmalara bakıldığında pozitif sosyal desteğin yabancı çalışanlar üzerinde olumlu bir etkisi olduğunu ortaya konmuştur (Kovacev ve Shute, 2004; Simich, Beiser ve Stewart, 2005; Goda ve Savolainen, 2017). Birçok araştırma ise sosyal desteğin, kişilerin psikolojik sorunlarının çözümü ve önlenmesi hatta tedavisinde önemli bir kaynak olduğunu belirtmektedir (Schweitzer, Greenslade ve Kagee, 2007). Fawley-King (2010). Konuyla ilgili olarak yapılan farklı çalışmalarda sosyal desteğin yaşam doyumunu arttırdığı (Dil ve Aykanat, 2016), mesleki olgunluk düzeyini arttırdığg (Sürücü, 2005), akademik başarıyı arttığı (Yıldırım, 2006; Ateş, 2015), yalnızlık duygusunu azalttığı (Köse, 2006; Duru, 2008),depresif durumları azalttığı (Sayar, 2006), stresle başa çıkma düzeyini arttırdığı (Demirtaş, 2007; Oppedal ve Heyerdahl, 2005), işe adanmışlık düzeyini arttırdığ (İnce, 2016), dışlanma üzerine olumsuz etkilerinin olduğu (Halis ve Demirel, 2016), stres düzeyini azalttığ1 (Woodhead, 2016; Sarros ve Sarros, 1992; Özbay, Palanc1, 2012), özyeterlilik düzeyini arttırdığ1 (Brouwers ve Tomic, 2001; Zhang ve LV, 2011), tükenmişlik düzeyini azalttığ (Cheuk ve Wong, 1995; Grrenglass ve Burke, 1997; Russell ve Altmaier, 1987), yılmazlık duygusunu arttırdığ1 (Rajendran, 2008; Panter-Brick, 2018; Curtis ve Cicchetti, 2007; Pieloch ve McCullough, 2016; Aydın, 2018; Esin ve Deniz, 2014; Ergün, 2016) göç sürecinde olumlu etkilerinin olduğu (McEwen, 2007; Reavell ve Fazli, 2017), psikolojik sağlığa olan yararları olduğu (Gündoğan, 2015) sonuçlarına ulaşılmıştır. Sonuç olarak çalışanların sosyal destek algılarına ilişkin çok sayıda kavramsal ve görgül çalışma bulunmasında rağmen turizm sektörü özelinde literatürün oldukça kısıtlı olduğu anlaşılmaktadır.

\section{Yöntem}

Çalışmada Sinop örneğinde turizm sektöründe çalışan yabancı çalışanların çalışma sorunları ve sosyal destek algılarının ortaya çıkarılması amacıyla keşifsel bir araştırma desenlenmiştir. Araştırma verileri, nitel araştırma yöntemlerinden derinlemesine görüşme tekniği ile toplanmıştır. Görüşmelerde katılımcılara Türkiye'ye geliş öyküleri, çalışma koşulları ve deneyimlerine ilişkin soruların yanı sıra, sosyal destek algılarına ilişkin sorular Zimet'in (1988) çalışması ışığında geliştirilerek sorulmuştur.

Katılımcıların belirlenmesinde kar topu örnekleme yöntemine başvurulmuştur. Kartopu örnekleme yöntemi zengin bilgiye sahip anahtar kişilere ulaşmak için kullanılan bir yaklaşımdır (Patton, 2002: 237). Ayrıca katılımcıların belirlenmesinde Türkiye' de belli bir süre yaşamış olmaları, çalışma deneyimine sahip olmaları ve Türkçe konuşabilmeleri belirleyici olmuştur. Görüşmeler 2019 Eylül ayında tamamlanmıştır. Kuramsal örnekleme yaklaşımı ş̧ı̆̆ında ortaya çıkan kavramlar ve süreçler birbirini tekrar etmeye başladığında, yeterli sayıda bireye ulaşıldığına karar verilmiş̧ir 
(Yıldırım ve Şimşek, 2011: 115). Toplam altı yabancı çalışan ile yapılan görüşmelerin ortalama süresi 26 dakikadır. Katılımcılarla ilgili bilgiler aşağıdadır:

Tablo 1: Kat1lımc1 Bilgileri

\begin{tabular}{|c|c|c|c|c|c|c|c|}
\hline $\begin{array}{l}\text { Katılımeı } \\
\text { kodu }\end{array}$ & Yaş & Cinsiyet & $\begin{array}{l}\text { Medeni } \\
\text { durumu }\end{array}$ & $\begin{array}{l}\text { Resmi } \\
\text { durumu }\end{array}$ & Geldiği ülke & $\begin{array}{l}\text { Kaç yıldır } \\
\text { Türkiye'de } \\
\text { olduğu }\end{array}$ & $\begin{array}{l}\text { Çalıştığ işletmenin } \\
\text { türü// Departman }\end{array}$ \\
\hline K1 & 21 & Erkek & Bekar & Mülteci & Irak & $4 y 11$ & $\begin{array}{l}\text { Yiyecek-içecek işletmesi / } \\
\text { Servis- Mutfak }\end{array}$ \\
\hline K2 & 26 & Erkek & Evli & Mülteci & İran & 6 yıl & $\begin{array}{l}\text { Yiyecek-içecek işletmesi / } \\
\text { Servis }\end{array}$ \\
\hline K3 & 39 & Kadın & Evli & Mülteci & İ̀ran & 3 yıl & $\begin{array}{l}\text { Yiyecek-içecek işletmesi / } \\
\text { Mutfak }\end{array}$ \\
\hline K4 & 19 & Erkek & Bekar & $\begin{array}{l}\text { Üniversite } \\
\text { öğrencisi }\end{array}$ & Azerbaycan & 3 yıl & $\begin{array}{l}\text { Yiyecek-içecek işletmesi / } \\
\text { Servis }\end{array}$ \\
\hline K5 & 23 & Erkek & Bekâr & $\begin{array}{l}\text { Üniversite } \\
\text { öğrencisi }\end{array}$ & Türkmenistan & 4 yıl & Otel / Servis \\
\hline K6 & 21 & Erkek & Bekâr & $\begin{array}{l}\text { Üniversite } \\
\text { öğrencisi }\end{array}$ & Türkmenistan & 3 yıl & $\begin{array}{l}\text { Yiyecek-içecek işletmesi / } \\
\text { Servis }\end{array}$ \\
\hline
\end{tabular}

Görüșmeler sırasına katılımcıların izniyle görüșmeler sırasında ses kaydı alınmıștır. Ses kayıtları deşifre edildikten sonra üç aşamalı kodlama prosedürüne tabi tutularak içerik analizi yapılmıştır. Buna göre kodlama; açık kodlama, eksenli kodlama ve seçici kodlama şeklinde gerçekleştirilmiştir (Neuman, 2006). Toplanan verilerin analizine rehberlik edecek doğrudan bir kavram yapısı olmadığı için tümevarımcı yaklaşımla Strauss ve Corbin'in (1990) önerdiği üzere verilerden çıkarılan kavramlara göre kodlama gerçekleştirilmiştir. Temalar belirlenirken benzerlik ve farklılık tekniği kullanılmıştır (Glaser ve Strauss, 1967). Analizler, nitel veri analiz programı olan Nvivo 11 yardımıyla yapılmıştır.

Araştırma bulgularının güvenirliğinin sağlanması için uzman araştırmacılara başvurulmuştur. Araştırmada elde edilen temaların kodlanması iki uzman kişi tarafından tekrar edilmiştir. Sonrasında kodlayıcılar arası görüş birliği sorgulaması yapılmıştır. Nitel verilerin analiz güvenirliliğinin sağlanmasında da Miles ve Huberman (1994: 64) tarafından geliştirilen görüş birliği ve görüș ayrılığı formülünden (Görüș birliği/ Görüș birliği + Görüș ayrılığı) yararlanılmıștır. Buna göre kodlayıcılar arasındaki güvenirlilik değeri 0,77 olarak bulunmuştur. Görüş ayrıllğı yaşanan temalar yeniden ele alınıp son hali verilmiştir.

\section{Bulgular}

Yapılan tematik analiz sonucunda, katılımcıların Türkiye'ye geliş nedenleri, burada edindikleri sosyal deneyimler, yaşadıkları çalışma sorunları ve gelecek algıları olmak üzere dört ana temaya ulaşı1mıştır.

\section{Türkiye'ye Geliş Nedenleri}

İlk olarak katılımcılardan üçünün, kendi ülkelerinde yaşadıkları siyasi gerilim ve çatışmalardan ötürü can güvenliklerinden endişe etmeleri nedeniyle Türkiye'ye geldiği görülmüştür. Bir katılımcı bu durumu şu şekilde ifade etmektedir:

"Devletimiz iyi değil. Konuşamıyorsun. Bir şey diyemiyorsun, öldürüyorlar. Eylem yapıyorlar. Çok kötü bir şey mesela. Sünnileri öldürüyorlar. Sadece Şii olması gerekiyor.” (K3)

Mülteci statüsüyle Türkiye'de bulunan bu katılımcıların dışındaki diğer katılımcıların, üniversite eğitimi amacıyla kendi arzularıyla Türkiye’ye geldikleri kaydedilmiştir. Bu katılımcılar, 
öğrencilik durumlarına bağlı olarak oturma izni almaktadır. Sonuç olarak katılımcıların Türkiye’ye geliş nedenlerinin ve buna bağlı olarak hukuki statülerinin farklılaştığı anlaşılmaktadır.

\section{2. Çalışma Sorunları}

Çalışmada ulaşılan bir diğer tema ise katılımcıların çalışma hayatlarına ilișkin sorunları kapsamaktadır. Bu tema altında ulaşılan alt temalar ise kayıtdışı çalışma, düşük ücret sorunu, çok çalışma zorunluluğu, niteliğine uygun iş bulamama, ülkeye ve şehre bağlı istihdam sorunlarıdır. Çalışmada tek bir kişi dışında görüşme yapılan katılımcıların, çalışma izni olmadan bir diğer ifadeyle kaçak olarak çalıştıııldıkları kaydedilmiştir. 4817 sayılı Yabancıların Çalışma İzinleri Hakkında Kanunu'na göre öğrencilik durumlarına bağlı olarak oturma izni alan kişilere çalışma izni verilmemekte, ancak mezun oldukları takdirde istisnai olarak çalışma izni verilmektedir (www.mevzuat.gov.tr). Buna göre öğrenci olan katılımcılar, kaçak olarak çalıştıklarını açıkça dile getirmektedir. Diğer yandan mülteci statüsünde olan katılımcılar, uluslararası koruma statüsünde olup çalışma izni alabilmektedir. Ancak Aile Çalışma ve Sosyal Hizmetler Bakanlığı'na göre çalışma izni almak, harç ve değerli kâğıt bedeli maliyetleri doğurmakta; Sosyal Güvenlik Kurumu'na kayıt yapılmasını takiben işverenin çalışanı için sigorta primi ödenmesini gerektirmektedir (www.ailevecalisma.gov.tr). Dolayısıyla katılımcılar kaçak ve sigortasız çalıştırılmaktadır. Bu durumu K2, şu şekilde ifade etmektedir:

"Çünkü bizim çalışma izni almak biraz zor. Neden çünkü bizim olmamız sizden daha pahalı olacak. Kaçak olarak çalışıyorum."

Katılımcıların dile getirdiği bir başka sorun ise düşük ücretlendirmedir. Öğrenci statüsünde olan bir katılımcı durumu şu şekilde açıklamaktadır:

"Şöyle söyleyeyim, yabancı olduğum için öncelikle çok düşük ücret teklif ediyor patronlar, iş sahipleri. Düşük ücreti de biz de mecbur olduğumuz için hemen kabul ettiğimiz için işi alabiliyoruz." (K4)

Katılımcıların çoğu ailelerinden destek görmemeleri dahası kendi ailelerine bakma sorumluluklarından ötürü çok çalışmak zorunda olduğunu ifade etmiştir. Dahası öğrenci statüsünde olan katılımcılar da çalışmak zorunda oldukları için Türkiye'ye geliş amacı olan eğitim amacının ikinci planda kaldığını belirtmiştir.

"Normal bir öğrenciye göre, normal işçi olarak çalışıyorum. Öğrencilik geri plana gitmiş gibi oluyor, bu derslerde de zor duruma sokuyor beni. Kötü oluyor. Hem şöyle bir şey var. İşi bıraksam, okulu bırakmak zorunda kalırım. Fazla para kazanmak zorundayım. Aileye de destek olmak zorundayım." (K4)

Katılımcıların karşılaştıkları bir başka sorun ise ülke ya da uygulamanın gerçekleştirildiği Sinop iline bağlı olarak ortaya çıkan istihdam talebi azlığ 1 ve sezonluk istihdam sorunudur. Bir katılımcı bu durumu şu şekilde özetlemektedir:

"Sinop'ta çok fazla iş seçeneğin yok... Sezonda fark ediyor. Sezonda her yerde çalışabilirsin. Her yer maaşını verir. Ama kış gelince elemanları çıkarmaya başlıyorlar. Ya da elemanlar kalır, maaş vermiyorlar." (K1)

İstihdam talebi eksikliğine ek olarak katılımcıların kendi niteliklerine uygun işler bulmakta zorlandıkları da kaydedilmiştir. Ayrıca katılımcıların tamamı çok çeşitli iş kollarında çalıştıklarını belirtmiştir. Sıklıkla dile getirilen iş alanı ise turizm sektörü içinde bulunan yiyecek-içecek hizmetleri olmuştur. Bir katılımcı bu durumu şu şekilde ifade etmektedir:

"Ben burada her yerde çalıştım. Çalışmadığım bir yer kalmadı. Çay bahçelerinde çalıştım. Restoranlarda garsonluk yaptım. İnşaatlarda çalıştım. Fırıncılık yaptım, pide ustasıyım.” (K1) 
Genel olarak bakıldığında çalışma hayatlarında katılımcıların bir dizi sorun yaşadığ kaydedilmiştir. Ancak çalışma izni olmadan kayıtdışı çalıştırılmanın başlıca sorun olduğu anlaşılmaktadır.

\section{Sosyal Deneyimler}

Analiz sonucunda elde edilen üçüncü tema katılımcıların sosyal deneyimlerine ilişkin bulguları kapsamaktadır. Bu tema altında Türkçe bilmenin sağladığı avantajlar, halkla uyum yaşama, halkla uyumsuzluk yaşama, özel sosyal çevreye sahip olma, iş ortamının desteği ve sosyal haklara ilişkin algılanan kısıtlılıklar alt temaları yer almaktadır.

İlk olarak Türkçe bilme avantajının katılımcıların hem iş hem sosyal hayatlarında önemli bir belirleyici olduğu bulgusuna erişilmiştir. Saha gözlemlerinde de tespit edildiği üzere katılımcılar genel olarak iyi düzeyde Türkçe konuşabilmektedir. Bir katılımcı dil öğrenme sürecini şu şekilde özetlemektedir:

“Ama mesela ilk gün geldik çok zor geçti. Çünkü dil bilmiyoruz. Hiç kimseyi hiçbir yeri tanımıyoruz. Sonra yavaş yavaş internetten televizyondan yavaş yavaş öğrendik... (Çocuklarım) okula gidiyorlar geliyorlar onlar daha kolay alıştı dili de öğrendiler. Ben bazen konuşuyorum, bana gülüyorlar... Dil bilmezsem nasıl çalışayım? Bunu ver onu al bunu yap. Çok güzel konuşamıyorum ama ufak tefek işlerimi halledebiliyorum.” (K3)

Türkçe bilmenin katılımcıların, sosyal alanda iletişimlerini artırarak varlıklarını göstermelerini kolaylaştırdığı anlaşılmaktadır. Ayrıca Türkçe bilmelerinin, turizm sektöründe kolaylıkla iş bulabilmelerine yardımcı olduğu görülmektedir.

Katılımcıların yabancı olmaları sebebiyle halkla uyumsuzluk yaşadığı durumlar ortaya çıkmaktadır. İlk olarak katılımcılar, insanların onlara kötü davranması ve dolandırılmaktan ötürü güven sorunu yaşadıklarını dile getirmiştir. Dahası çok baskın olmamakla birlikte yerel halkın onları istememesi, bu durumu hareket ve söylemlerine yansıttığı durumlar yaşandıkları kaydedilmiştir. Bir katılımcı bu durumu şu sözlerle örneklendirmektedir:

"Bize bakıyorlar ya da bazen bir komşumuz O hep diyordu Allah sizin belanızı versin gidin kendi memleketinize, niye buraya geldiniz diye konuşuyordu." (K3)

Bazı katılımcılar haklarının oldukça kısıtlı olduğunu dile getirmiştir. Örneğin kredi kartı sahibi olamadıklarını belirten K2 ve K3; yabancı olmalarından ötürü uygulanan politikalar karşısında zorluk çektiklerini açıklamaktadır. Bir başka kısıtlılık ise hareket serbestliğine ilişkindir. Uluslararası koruma statüsüne bağlı olarak mülteci olan bu katılımcılar, ülkelerarası seyahat edemedikleri gibi ülke içi seyahatlerinde de izne tabi olduklarından hareket serbestliğine sahip değildir.

Olumsuz durumların yaşanmasına rağmen katılımcıların kabullenici bir yaklaşımla olumsuzlukları normalleştirdiği de izlenmektedir. Genel olarak sosyal çevrelerinden memnuniyetleri sorulduğunda katılımcılar, yaşadıkları sıkıntılara rağmen mevcut durumlarından şikayetçi olmadıklarını dile getirmektedir. Bu noktada tam olarak sosyal destek algısının, sosyal destekten bağımsız olarak kişiler üzerinde etkili olduğu anlaşılmaktadır. Ayrıca bu bulgu, katılımcıların halkla uyum sağlayabildikleri de göstermektedir. Dahası yerel halktan yardım aldıklarını, şehri sevip benimsediğini belirten katılımcılar da olmuştur. Bu bulgular, katılımcıların duygusal ve bazen de maddi destek gördüklerini göstermektedir. Bazı katılımcılar bu durumu şu şekilde ifade etmektedir:

"Ustalarım hakikaten iyi insanlar. En kötü zamanlarımda bana yardım ettiler. Ev tuttum, para verdiler. Şimdi ben aramasam onlar arıor. Böyle insanlar da var. Kötü insanlar da var. Her zaman derim beş parmak aynı değil. Türkiye'de iyi insanlar da var kötü insanlar da.” (K2)

“Tabi herkes kötü değil. Böyle dersek nankörlük yapmış oluruz.” (K5) 
Katılımcıların kendilerine özel sosyal çevreler geliştirdikleri de anlaşılmaktadır. Özellikle öğrenci olan katılımcıların kendileri gibi yabancı öğrencilerle özel sosyal alanlar kurdukları görülmektedir. İş bulma ve konaklama gibi ihtiyaçları söz konusu olduğunda kendi içlerinde dayanışma göstermektedirler. Bu bulgu, katılımcıların kendi özel ağ yapılarında beraberlik ve bilgisel destek geliştirdiklerini işaret etmektedir. Bunun yanı sıra uygulama yapılan şehir olan Sinop'un küçük bir şehir olması sebebiyle katılımcıların kolaylıkla işlevsel ağlar geliştirebildiği anlaşılmaktadır.

Son olarak katılımcılar, özel sosyal çevrelerinin dişında iş ortamında da genel olarak desteklendiklerini ifade etmektedir. Her ne kadar kaçak ve sigortasız çalıştırılma, düşük ücret gibi sorunlarını dile getirseler de iş ortamlarından memnun oldukları anlaşılmaktadır. İş arkadaşları ve işverenlerinin onlara olumlu ve yardımsever olduklarını belirtmişlerdir. Bu bulgu, çalışma ortamında katılımcıların bilgisel ve duygusal destek algılarına ilişkin kanıt oluşturmaktadır. Bir katılımcı bu durum hakkında şunları söylemektedir:

"Diğer çalışanlarla aramız çok iyi, hiç sıkıntımız yok. Asla. Patronumuz çok iyi garsonlar çok iyi mutfak aşçı çok iyi davranıyorlar." (K3)

Sonuç olarak bakıldığında en az üç senedir Türkiye'de yaşayan katılımcıların halkla baskın olmamak kaydıyla uyumsuzluklar yaşadığ 1 görülmektedir. Ancak özellikle dil sorunu yaşamayıp halkla daha çok iletişim kurdukça bir uyum sağlanabildiği de görülmektedir. Ayrıca katılımcıların arkadaşları, iş arkadaşları ve işverenlerinden bilgisel ve duygusal destek gördükleri anlaşılmaktadır.

\section{Gelecek algiları}

Katılımcılara yönlendirilen sorular sonucunda elde edilen veriler onların gelecek algılarına ilişkin bazı bulgulara ulaşılmasını sağlamıştır. Baskın olarak katılımcıların gelecek algısının belirsizlik üzerine olduğu görülmektedir. Özellikle mülteci katılımcılar uzun ya da kısa vadede plan yapamadıklarını dile getirmiştir.

"Belli değil 5 sene sonra 1 ay sonra başka bir ülkeye de gönderebilirler. Çok insanlar gittiler. Bizi daha hala aramadılar bekliyoruz şu anda." (K1)

Öğrenci olan katılımciların ise plan yapmaya daha uygun durumda olmakla beraber tam bir kariyer planına sahip olmadıkları görülmüştür.

"Kafamda bir sürü plan var. Bunlardan bir yüksek lisans yapmak. Türkiye'deyim yurt dışında Rusya da ya da Amerika'da. Bu olmazsa Amerika'ya gideceğim. Amerika'da kendimi toparlayacağım... yani finansal olarak." (K5)

Diğer yandan mülteci katılımcıların, her ne kadar geleceklerini belirsiz görmekte ve plansızlık yaşasalar dahi "hayaller "ini dile getirmekten çekinmedikleri görülmektedir.

"Hayallerim var. 70 yaşına da gelsem bu hayalleri yapmayı istiyorum. Mesela ben bilgisayar mühendisiyim... Çok büyük bir şirket kurayım. 100-150 kişi fakir akıllı zeki insanları işe alayım." (K2)

Sonuç olarak belirsiz gelecek algıları ve plansızlığın katılımcıları belli bir çalışma alanında uzmanlaşmaktan ya da kariyer planı yapmaktan alıkoyduğu anlaşılmaktadır. Bu durum katılımcıların turizm sektörünü geçici bir çalışma alanı olarak algıladıklarını göstermektedir.

\section{Tartışma ve Sonuç}

Turizm sektöründe çalışan yabancıların yaşadıkları sorunlar ve sosyal destek algılarının incelenmesi amacıyla Sinop örneğinde uygulaması gerçekleştirilen çalışma, yabancı çalışanların bir dizi çalışma sorunu yaşamalarına rağmen sosyal destek algılarının düşük olmadığını göstermiştir. 
Belirlenen temalar ışı̆̆ında çalışma hayatlarının ve Türkiye'de bulunmalarının pozitif bir etki ve olumlu bir algısal süreçte devam ettiğine yönelik bulgulara ulaşılmıştır.

Öncelikle katılımcılardan alınan görüşlere göre yabancı çalışanlarda kayıtdışı çalışma durumu, düşük ücret sorunu, niteliksizleştirme gibi sorunların öne çıktığı anlaşılmıştır. Katılımcılar, yabancılık hallerinin bir dezavantaj olmasından ötürü normal koşullara kıyasla daha az ücretle çalıştırılmakta, işverenler için çalışma izni almak bir maliyet unsuru olduğundan kayıtdışı ve sosyal güvencesiz çalışmak durumunda bırakılmaktadırlar. $\mathrm{Bu}$ durum literatürün de işaret ettiği bir sorun olmuştur (Demir, 2016; Lordoğlu, 2007; Gökmen, 2011; Araslı vd., 2019). Diğer yandan bu durum Türkiye'nin içerisinde bulunduğu ekonomik koşullar ve çalışma hayatındaki dalgalı istihdam politikalarının yaşanması sebebiyle doğal bir süreç olarak karşılanmakta aynı zamanda denetim yetersizliği sebebiyle de işletmelerin yasalara aykırı bu durumda çalışanları istihdam etmeleri noktasında cesaretlendirici bir unsur olarak kabul edilmektedir.

Niteliklerine uymayan işlerde çalıştıklarını düşünen katılımcılar Gökmen'in (2011) çalışmasında yer alan niteliksizleştirme sorununa da kanıt teşkil etmektedir. Katılımcıların kendi ülkelerinde görmüş oldukları yükseköğretim düzeyleri ve alanlarının dışında veya zanaat olarak kabul edilebilen alanlardaki bilgi ve becerileri düşük vasıf gerektiren iş kollarında çalışmaları sebebiyle göz ardı edilmektedir. Bu durumun temel sebepleri ilgili konulardaki çalışma alanlarının farklılık göstermesi ve yabancı çalışanların çalıştıkları iş kollarının eğitim gerektiren meslek kollarına yaklaştıkça ücretlerin artmasının yanında kayıtlı hale getirilmelerinin zorunluluk gerektirdiği gerçeğidir. Ancak bu durumda ortaya çıkan karışıklık ise yabancı çalışan durumunda olan kişilerin Türkiye'de bulunma statülerinin çalışma hayatlarına olan hukuki etkileridir.

Çalışma hayatı ile ilgili sorunlara ek olarak sosyal deneyimlerinde de yabancıların sosyal kabule ilişkin olumsuz durumlar yaşadığı kaydedilmiştir. Ancak bu kişiler içinde bulundukları bu karmaşı durumu, kendi ülkeleri ile karşılaştırdıklarında kabul edilebilir ve aynı zamanda da geçici olarak görebilmekte, bunun yarattığı bir sonuç olarak da mevcut durumlarını geçici bir süreç olarak algılamakta ve çalıştıkları bu süreci katlanılabilir olarak görmektedirler.

$\mathrm{Bu}$ veriler ışığında çalışmanın ortaya çıkan en önemli sonuç, yaşadıkları sıkıntı ve sorunlara kıyasla yabancı çalışanların sosyal destek algılarının nispeten yüksek olmasıdır. Esasında bu durum sosyal destek ve sosyal destek algısı arasındaki farkı vurgulamaktadır. Algısallık değişkeni sosyal desteğin yeterliliğini etkilemektedir. Nitekim çalışmada doğrudan yabancılarla görüşülerek öznel değerlendirme yapmaları istenmiş ve çalışanların geçmiş yaşantılarının da olası etkileriyle kabullenici bir yaklaşım izleyerek mevcut sosyal desteği yeterli görebildikleri izlenmiştir. Buradaki kabullenme algısı ve düşüncesi genel olarak Türkiye'de bulunmalarına neden olan kendi ülkelerindeki durumların, mevcut yaşam şartlarından daha kötü ve tehlikeli olarak nitelendirmelerinden kaynaklanmaktadır.

Çalışanların ilgili çevreye göre farklılaşmakla birlikte çoğunlukla duygusal destek gördükleri anlaşılmıştır. Kendi özel çevrelerinden duygusal, beraberlik ve bilgi desteği; çalışma çevrelerinden ise duygusal ve bilgi desteği aldıkları görülen yabancılar, tüm çevrelerinden nadiren de olsa maddi destek alabilmektedir. Bu noktada kişilerin yaşamak ve/veya çalışmak için Türkiye'yi seçmelerinde sosyo-kültürel yapının ve daha önceden edindikleri bilgilendirmelerin yaşam koşulları açısından uygunluğu kabul edilebilir olmasının da etkisi büyüktür. Algılanan sosyal destek, sorunlara rağmen katılımcıların yaşamlarını sürdürmelerini desteklemekte yaşadıkları toplumun bir parçası olmalarını kolaylaştırmaktadır.

Sektör temelinde bakıldığında; emek yoğun, mevsimsellik ve düşük vasıf gerektiren işleri de içinde bulunduran geniş iş ölçeği, yabancıların istihdamı için turizmi kolaylaştırıcı ve uyumlaştırıcı bir sektör kılmaktadır. Özellikle Türkçe öğrenebilen yabancılar, farklı kültürlere nispeten açık olan turizm sektöründe yer bulabilmektedir. Ancak bulgular bulundukları hukuksal durumlardan ötürü katılımcıların uzun vadede plan yapamamaları ve belirsizlik içinde olduklarını göstermektedir. $\mathrm{Bu}$ 
durum katılımcıların belli bir kariyer planı yapamamalarına yol açmaktadır. Bu bağlamda Baum'un (2012) belirttiği üzere turizm sektöründe yabancı çalışanların kısa vadeli planlar yapmalarını ve turizmi geçici olarak görmeleri yaklaşımı desteklemektedir. Öte yandan turizmi milli gelir açısından kalkınmanın önemli bir parçası olarak belirleyen ekonomilerde, uzun vadeli stratejik personel planlamasının yanında kalitenin de vazgeçilmez bir süreklilik unsuru olması, yabancı çalışanlar konusunda daha hassas ve hukuki davranılması gerekliliğini ortaya koymaktadır. Ancak bu unsurun yerine getirilememesi hem personel sayısı ve kalitesi hem de yasal olarak uygulamalar açısından önemli stratejik açıklar meydana getirmektedir. Böylece sektördeki belirsizlikler çalışma alanı olarak ilk değerlendirilebilecek alan olarak turizm sektörünü göstermektedir. Yabancı çalışanlar için turizm sektörünün geçici bir çalışma alanı olarak görülmesi hem sektörün uygunluğu hem de izlenen politikaların belirsizliğine bir de gelecekle ilgili olarak, yabancıların yaşadığı belirsizlik eklenmekte bu durum ise sektörel bir dengesizliğe sebep olmaktadır. Sonuç olarak yabancı istihdam politikası iyi planlanması ve yönetilmesi gereken bir sorunsala dönüşmektedir.

Çalışma sonuçlarına göre birtakım önerler de bulunmak mümkündür. Öncelikle ülke ekonomisi ve turizm hizmet kalitesine yönelik olarak denetimlerin arttırılması, kayıtdışı çalışan yabancıların kayıt altına alınarak piyasadaki ekonomik dengeler gözetilmeli aynı zamanda da turizm çalışanları için sosyal güvenceler sağlanmalıdır. Bunun makro sonuçları olarak da haksız rekabeti engelleyecek ücret ve vergi politikalarının uygulanma alanlarının genişletilmesi, bütün turizm sektörü çalışanlarının eşit sosyal ve ekonomik hakları elde etmeleri sağlanmalıdır. Böylece karşılıklı hak ve özgürlüklerin yasalar çerçevesinde belirlenmiş bir turizm sektör çalışan profili oluşturularak, kalite, sosyal destek, ücret ve en nihayetinde öngörülebilir bir turizm politikası uygulanabilecektir. $\mathrm{Bu}$ durumda da turizm işletmeleri daha düşük ücretlerle sosyal güvencesi olmayan aynı zamanda da vergilendirilmeyen yabancı çalışanlara yönelmek yerine sektörün ihtiyacı olan kalifiyeli, bilinçli ve ülke ekonomisi için de faydalı çalışanları tercih edeceklerdir. Ancak buradaki tercihin kaynağının işgücüne uygun çalışanın yasalar çerçevesinde yerli ya da yabancı çalışan ayrımı yapılmadan kalite odaklı olarak düşünülmesi gerekmektedir. Kalite odaklı personel planlaması ise her zaman rekabeti ve sürdürülebilir kalite anlayışını sağlayacaktır.

\section{Araştırma Sınırlılıkları}

Araştırma Sinop örneğinde gerçekleştirilmesi dolayısıyla örneklem bakımından sınırlılığa sahiptir. Görüşme dilinin Türkçe olması da örneklem belirlerken katılımcıların Türkçe bilmesi sınırlılığını getirmiştir. Bir başka sınılılık ise katılımcıların sorulara yanıt verecek deneyime sahip olacak kadar Türkiye'de yaşamaları ve çalışmaları gerekli görüldügünden, katılımcıların Türkiye'de kalış sürelerinin en az 3 yıl olmasıdır. Ayrıca örneklemin Türkiye'ye geliş nedenlerine göre genel olarak iki gruba ayrıldığı görülmektedir. Gelecek çalışmalarda Türkiye'ye geliş nedenine / resmi statülerine göre örneklem belirlenerek homojen gruplarda ya da heterojen ancak daha geniş örneklem büyüklüğünde çalışmalar yapılması önerilmektedir.

\section{Kaynakça}

Arasli, H., Arici, H. E. ve Ilgen, H. (2019). Blackbox between job crafting and job embeddedness of immigrant hotel employees: a serial mediation model. Economic Research-Ekonomska Istrazivanja, 32(1), 3935-3962.

Ataç, Ö., Akbay, H., Dobral, A., Demir, S., Ateş, B. S., Ahmedzai, S. ve Hayran, O. (2018). Mülteci ve yerleşik ergenlerde depresyona yatkınlık ve algılanan sosyal destek düzeyleri. Anatolian Clinic the Journal of Medical Sciences, 23(3), 129-136.

Ateş, B. (2015). Üniversite Öğrencilerinde Güvengenliğin Yordayıcısı Olarak Sosyal Destek Algıları, Mehmet Akif Ersoy Üniversitesi Eğitim Fakültesi Dergisi, 35, 70-86. 
Aydın, E. (2018). Çocukluk Çağı Travmatik Yaşantılarının Psikolojik Sağlamlık Ve Depresyon Belirtileri Üzerine Etkisi. Yayımlanmamış Yüksek Lisans Tezi, Fatih Sultan Mehmet Vakıf Üniversitesi, Sosyal Bilimler Enstitüsü.

Barrera, M., Sandler, I. N. ve Ramsay, T. B. (1981). Preliminary development of a scale of social support: Studies on college students. American Journal of Community Psychology, 9(4), 435447.

Baum, T. (2012). Migrant workers in the international hotel industry. Geneva: International Labour Office.

Boldwin, L.A. (1967). Theories of Child Development. John Willey and Sons, Inc. New York.

Brouwers, A., Evers, W. J. ve Tomic, W. (2001). Self- Efficacy İn Eliciting Social Support And Burnout Among Secondary- School Teachers. Journal Of Applied Social Psychology, 31(7), 1474-1491.

Bruhn, J. G., ve Philips, B. Y. (1984). "Measuring Social Support: A Synthesis of Current Approaches". Journal of Behavioral Medicine, 7,150-170.

Caplan, G. (1974). Support Systems And Community Mental Health. New York: Behavioral Publications.

Cassel, J. (1976). The Contribution Of The Social Environment To Host Resistance: The Fourth Wade Hampton Frost Lecture. American Journal Of Epidemiology, 104(2), 107-123.

Ceylan, V., Algan, C., Yalçın, M., Yalçın, E., Akın, E. ve Köse, S. (2017). Suriyeli mülteci ve sığınmacıların çeşitli psikolojik faktörler açısından incelenmesi: Batman örneklemi. International Journal of Social Sciences and Education Research, 3(2), 595- 606.

Cheuk, W. H. ve Wong, K. S. (1995). Stress, social support, and teacher burnout in Macau. Current Psychology, 14(1), 42-46.

Cobb, S. (1976). Social Support As A Moderator Of Life Stress. Psychosomatic Medicine, 38(5), 300-314.

Cohen, S. Ve Wills, T.A. (1985). Stress, Social Support and The Buffering Hypothesis, Psychological Bulletin, 98(2), 310-357.

Cohen, S. ve Janick-Deverts, D. (2009). Can We Improve Our Physical Health By Altering Our Social Networks? Physical Health And Social Networks: Perspectives On Psychological Science, 4(4), 375-378.

Coyne, J. C., ve Downey, G. (1991). Social Factors And Psychopathology: Stress, Social Support, And Coping Processes. Annual Review of Psychology, 42, 401-425.

Coyne, J. C., Ellard, J. H., ve Smith, D. A. F. (1990). Social Support, İnterdependence, And The Dilemmas Of Helping. İçinde B. R. Sarason, I. G. Sarason, \& G. R. Pierce (Ed..), Wiley Series On Personality Processes. Social support: An interactional view (s. 129-149). John Wiley \& Sons.

Curtis, W. J., ve Cicchetti, D. (2007). Emotion And Resilience: A Multilevel İnvestigation Of Hemispheric Electroencephalogram Asymmetry And Emotion Regulation İn Maltreated And Nonmaltreated Children. Development and psychopathology, 19(3), 811-840.

Çakır, Y. ve Palabıyıkoğlu, R. (1993). Gençlerde Sosyal Destek-Çok Boyutlu Algılanan Sosyal Destek Ölçeğinin Güvenirlik ve Geçerlik Çalışması. Kriz Dergisi, 5(1), 15-24.

Demir, M. (2016). Türkiye’ de Yabanc1ların Sosyal Güvenliği, Sosyal Güvenlik Dergisi, 6(1), 70-93. 
Demir, Ö.O., ve Aliyev, R. (2019). Resilience Among Syrian University Students İn Turkey. Turkish Journal of Education, 8(1), 33-51. https://dx.doi.org/10.19128/turje.454138

Demirtaş, A.S. (2007). İlköğretim VIII. Sınıf Öğrencilerinin Algılanan Sosyal Destek ve Yalnızlık Düzeyleri ile Stresle Başa Çıkma Düzeyleri Arasındaki Illişki. Yayınlanmamış Yüksek Lisans Tezi, Gazi Üniversitesi. Eğitim Bilimleri Enstitüsü.

Dil, S. ve Aykanat Girgin, B. (2016). Hemşirelik Öğrencilerinin Öfke, Umutsuzluk, Stresle Baş Etme Düzeyleri ile Sosyal Destek Algıları Arasındaki İlişkinin İncelenmesi, Psikiyatri Hemşireliği Dergisi, 7(3), 121-128.

Durkheim, E. (1897). "İntihar Toplum Bilimsel İnceleme” (çev. Ö. Ozankaya). İmge Kitabevi Yayıncılık. (Eserin orijinali 1986' da yayımland1).

Duru, E. (2008). Üniversiteye Uyum Sürecinde Yalnızlığı Yordamada Sosyal Destek ve Sosyal Bağlılığın Doğrudan ve Dolaylı Rolleri, Türk Psikolojik Danışma ve Rehberlik Dergisi, 3(29), 13-24.

Ekiz Gökmen, Ç. (2011). Türk Turizminin Yabanc1 Gelinleri: Marmaris Yöresinde Turizm Sektöründe Çalışan. Çalışma ve Toplum, 1, 221-232.

Ergün, O. (2016). Ergenlerde duygusal zeka özellikleri ile psikolojik sağlamlık arasındaki ilişkinin incelenmesi. Yayınlanmmaıs yüksek lisans tezi, İstanbul Arel Üniversitesi, Sosyal Bilimler Enstitüsü.

Esin, Ö. ve Deniz, M. E. (2014). Üniversite Öğrencilerinin Psikolojik Sağlamlık Düzeylerinin Duygusal Zekâ Açısından İncelenmesi. Illkögretim Online, 13(4), 1240-1248. DOI: 10.17051/io.2014.74855

Fawley-King, K. (2010). A Review Of Family-Based Mental Health Treatments That May Be Suitable For Children İn İmmigrant Families İnvolved İn The Child Welfare System. Journal of Public Child Welfare, 4 (3), 287-305. Doi: 10.1080/15548732.2010.496081

Gez, A. (2018). Suriyeli Çocuk Ve Ergenler Algllanan Sosyal Destek Ve Psikolojik Sağlamlık Arasındaki İlişki. Yayınlanmamış Yüksek Lisans Tezi, Çă̆ Üniversitesi, Sosyal Bilimler Enstitüsü, Mersin.

Glaser, B. G., ve A. Strauss. (1967). The Discovery Of Grounded Theory: Strategies For Qualitative Research. New York: Aldine

Goda-Savolainen, M. (2017). Social support and well-being of refugees in Finland. Yayınlanmamış Yüksek Lisans Tezi. University Of Jyväskylä, Intercultural Communication Master's Degree Programme İn Intercultural Communication.

Gökler, I. (2007). Çocuk Ve Ergenler İçin Sosyal Destek Değerlendirme Ölçeği Türkçe Formunun Uyarlama Çalışması: Faktör Yapısı, Geçerlik Ve Güvenirliği. Çocuk ve Gençlik Ruh Sağlı̆̆ Dergisi, 42(1), 43-54.

Greenglass, E. R., Burke, R. J. ve Konarski, R. (1997). The Impact Of Social Support On The Development Of Burnout İn Teachers: Examination Of A Model. Work ve Stress, 11(3), 267278.

Gündoğan, N. (2015). Türkiye'de Yaşayan Siğınmacı Ve Mültecilerin Psikososyal Gereksinimleri Ve Psikolojik Belirtileri. Yayınlanmamış Yüksek Lisans Tezi, Ankara Üniversitesi, Sosyal Bilimler Enstitüsü, Ankara.

Halis, M., ve Demirel, Y. (2016). Sosyal Desteğin Örgütsel Soyutlama Dışlanma Üzerine Etkisi. Kastamonu Üniversitesi İktisadi ve İdari Bilimler Fakültesi Dergisi, 111, 318-335. 
Heyerdahl S, Halvorsen I, Andersen A, (2005). Good Outcome Of Adolescent-Onset Anorexia Nervosa After Systematic Treatment. Intermediate To Long-Term Follow-Up Of A Representative County-Sample. Euro Child Adolesc Psychiatry 13, 295-306

Hupcey, J. E. (1998). Social Support: Assessing Conceptual Coherence. Qualitative Health Research, 8(3), 304-318.

İnce, A. R. 2016. Algılanan Örgütsel Desteğin İşe Adanmışlık Üzerindeki Etkisinde Yönetici Desteğinin Aracılık Rolü. Elektronik Sosyal Bilimler Dergisi, S.1557.

Kaner, S. (2002). Aile Destek Ölçeği: Faktör Yapısı, Güvenirlik Ve Geçerlik Çalışması, XI. Ulusal Özel Ĕ̈itim Kongresi Bildirileri, Eğitim Kitabevi Yayınları.

Kara, P. Ve Korkut, R. (2010). Türkiye'de Göç, İltica Ve Mülteciler. Türk İdare Dergisi, 467, 153162.

Karaman, H. B. (2018). Göçmen Ortaokul Öğrencilerindeki Travma Sonrast Stres Bozukluğu, Sosyal Destek ve Depresyon Durumlarının İncelenmesi. Yayınlanmamış Yüksek Lisans Tezi, Bolu Abant İzzet Baysal Üniversitesi, Eğitim Bilimleri Enstitüsü, Bolu.

Kovacev, L., ve Shute, R. (2004). Acculturation And Social Support İn Relation To Psychosocial Adjustment Of Adolescent Refugees Resettled İn Australia. International Journal of Behavioral Development, 28(3), 259-267.

Köse, E. (2006). Liseli Ergenlerde Kişilik Ve Sosyal Desteğin Yalnızlı̆̆a Olan Etkisinin İncelenmesi, Yayımlanmamış Yüksek Lisans Tezi, Marmara Üniversitesi Eğitim Bilimleri Enstitüsü, İstanbul.

Lordoğlu, K. (2007). Türkiye'deki Çalışma Hayatının Bir Parçası Olarak Yabancı Çalışanlar, Çalışma Ve Toplum, 3(2007), 11-31.

Mcewen, E.P. (2007). Risk And Resilience İn Refugee Children. Yayımlanmamış Yüksek Lisans Tezi, University Of University Of Saskatchewan Saskatoon, Department Of Educational Psychology And Special Education.

Meral, B. F., ve Cavkaytar, A. (2012). Çok Boyutlu Algılanan Sosyal Destek Ölçeği'nin Psikometrik Özelliklerinin Otizmli Çocuk Aileleri Üzerinden İncelenmesi. E- International Journal Of Educational Research, 3(4), 20- 32.

Merrill Weine, S., Ware, N., Hakizimana, L., Tugenberg, T., Currie, M., Dahnweih, G., Wagner, M., Polutnik, C., Ve Wulu, J. (2014). Fostering Resilience: Protective Agents, Resources, And Mechanisms For Adolescent Refugees' Psychosocial Well- Being. Adolescent Psychiatry, 4(3), 164-176.

Miles, M. B. Ve Huberman, A. M. (1994). Qualitative Data Analysis: An Expanded Sourcebook. London: Sage.

Neuman, L. (2006). Toplumsal Araştırma Yöntemleri: Nitel Ve Nicel Yaklaşımlar. (Çev., Sedef Özge). Ankara: Yayın Odası.

Oppedal, B., Røysamb, E., Ve Heyerdahl, S. (2005). Ethnic Group, Acculturation, And Psychiatric Problems In Young Immigrants. Journal Of Child Psychology And Psychiatry, 46(6), 646660.

Özbay, Y., Palancı, M., Kandemir, M. ve Çakır, O. (2012). Üniversite Öğrencilerinin Öznel İyi Oluşlarının Duygusal Düzenleme, Mizah, Sosyal Özyeterlik Ve Başa Çıkma Davranışları İle Yordanmas1. Türk Ĕgitim Bilimleri Dergisi, 10(2), 325-345. 
Panter-Brick, C., Hadfield, K., Dajani, R., Eggerman, M., Ager, A., ve Ungar, M. (2018). Resilience İn Context: A Brief And Culturally Grounded Measure For Syrian Refugee And Jordanian Host-Community Adolescents. Child development, 89(5), 1803- 1820.

Patton, M. Q. (2002). Qualitative research and evaluation methods. Thousand Oakes.

Pieloch, K. A., McCullough, M. B., ve Marks, A. K. (2016). Resilience Of Children With Refugee Statuses: A Research Review. Canadian Psychology/Psychologie Canadienne, 57(4), 330339.

Rajendran, K. (2008). Impact of relationship with the caregiver and positive future expectations on behavioral and emotional resilience in adolescents in child welfare. Yayınlanmamıs doktora tezi, State University of New York, Albany, NY.

Reavell, J., ve Fazil, Q. (2017). The Epidemiology Of PTSD And Depression İn Refugee Minors Who Have Resettled İn Developed Countries. Journal Of Mental Health, 26(1), $74-83$.

Reinhardt, J. P., Boerner, K., ve Horowitz, A. (2008). Good To Have But Not To Use: Differential İmpact Of Perceived And Received Support On Well-Being. Journal of Social and Personal Relationships, 23(1), 117-129.

Richman. J. M., ve Rosenfeld L.B. (1987). Stress Reduction For Hospice Workers: A Support Group Model. Hospice Journal, 3, 205-22 1.

Russell, D. W., Altmaier, E. ve Van Velzen, D. (1987). Job-Related Stress, Social Support, And Burnout Among Classroom Teachers. Journal Of Applied Psychology, 72(2), 269.

Sarason, B. R., Sarason, I. G., Hacker, T. A., Ve Basham, R. B. (1985). Concomitants Of Social Support: Social Skills, Physical Attractiveness, And Gender. Journal Of Personality And Social Psychology, 49(2), 469-480.

Sarason, I. G., Levine, H. M., Basham, R. B., Ve Sarason, B. R. (1983). Assessing Social Support: The Social Support Questionnaire. Journal Of Personality And Social Psychology, 44, 127 139.

Sarros, J. C. ve Sarros, A. M. (1992). Social Support And Teacher Burnout. Journal Of Educational Administration, 30(1).

Sayar, M. (2006). A Longitudinal Study Of The Relationship Between Perceived Social Support And Psychological Well- Being Of Adolescents From Low Socioeconomic Status, Yayımlanmamış Yüksek Lisans Tezi, Boğaziçi Üniversitesi Sosyal Bilimler Enstitüsü, İstanbul.

Schweitzer, R., Greenslade, J., Ve Kagee, A. (2007). Coping And Resilience İn Refugees From The Sudan: A Narrative Account. Australian \& New Zealand Journal Of Psychiatry, 41(3), 282288.

Schweitzer, R., Melville, F., Steel, Z., Ve Lancherez, P. (2006). Trauma, Postmigration Living Difficulties, And Social Support As Predictors Of Psychological Adjustment In Resettled Sudanese Refugees. Australian And New Zeland Journal Of Psychiatry, 40 (2), 179-188.

Simich, L., Beiser, M., Stewart, M., ve Mwakarimba, E. (2005). Providing Social Support For İmmigrants And Refugees In Canada: Challenges And Directions. Journal Of Immigrant And Minority Health, 7(4), 259-268.

Sorias, O. (1988). Sosyal Destek Kavramı. Ege Üniversitesi Tıp Fakültesi Dergisi, 27(1), 353-357. 
Strauss, A., Ve Corbin, J. (1990). Basics Of Qualitative Research. Newbury Park: Sage Publications. Şimşek, H., Ve Ylldırım, A. (2011). Sosyal Bilimlerde Nitel Araştırma Yöntemleri. Ankara: Seçkin Yayıncılık.

Stromborg, M.F., Olsen, S.J. (1997). Instruments For Clinical Health Careresearch. Second Edition, USA.

Sürücü, M. (2005). Lise Öğrencilerinin Mesleki Olgunluk Ve Alglladikları Sosyal Destek Düzeylerinin İncelenmesi, Yayımlanmamış Yüksek Lisans Tezi, Gazi Üniversitesi Eğitim Bilimleri Enstitüsü, Ankara.

Taysi, E. (2000). Benlik Saygısl, Arkadaşlardan Ve Aileden Sağlanan Sosyal Destek: Üniversite Öğrencileriyle Yapılan Bir Çalışma. Yayımlanmamış Yüksek Lisans Tezi. Ankara Üniversitesi Sosyal Bilimler Enstitüsü. Ankara.

T.C. Mevzuat Bilgi Sistemi (Erişim tarihi: 4.10.2019) http://www.mevzuat.gov.tr/Metin.Aspx?MevzuatKod=7.5.6244\&MevzuatIliski=0\&source $\mathrm{XmlSearch}=$ yabanc\%C4\%B 1lar\%C4\%B1n\%20\%C3\%A7al\%C4\%B1\%C5\%9Fma

T.C. Aile Çalışma ve Sosyal Hizmetler Bakanlığı (Erişim tarihi: 4.10.2019) https://www.ailevecalisma.gov.tr/uigm/calisma-izni/basvuru-kilavuzlari/

Thoits, P. A. (1982). Conceptual, Methodological, And Theoretical Problems İn Studying Social Support As A Buffer Against Life Stress. Journal of Health and Social Behavior, 145-159.

Thoits, P.A. (1995). "Stress, Coping, and Social Support Processes: Where Are We? What Next?" Journal of Health and Social Behavior, Extra Issue, 53-79.

Uchino, B. N. ve Garvey, T. S. (1997). The Availability Of Social Support Reduces Cardiovascular Reactivity To Acute Psychological Stress. Journal Of Behavioral Medicine, 20, 15-27.

Ünüvar, A. (2003). Çok Yönlü Algılanan Sosyal Desteğin 15-18 Yaş Arası Lise Öğrencilerinin Problem Çözme Becerisine Ve Benlik Saygısına Etkisi. Yayınlanmamış Yüksek Lisans Tezi, Selçuk Üniversitesi, Sosyal Bilimler Enstitüsü, Konya.

Werner, E. E. (2012). Children And War: Risk, Resilience, And Recovery. Development And Psychopathology, 24(2), 553-558.

Woodhead, E. L., Northrop, L., ve Edelstein, B. (2016). Stress, Social Support, And Burnout Among Long-Term Care Nursing Staff. Journal Of Applied Gerontology, 351, Pp. 84-105.

Yıldırım, İ. (1997). Algılanan Sosyal Destek Ölçeğinin Geliştirilmesi, Güvenirliği ve Geçerliği. Hacettepe Üniversitesi Ĕ̈itim Fakültesi Dergisi, 13, 81-87.

Yıldırım, İ. (1998). Akademik Başarı Düzeyleri Farklı Olan Lise Öğrencilerinin Sosyal Destek Düzeyleri. Psikolojik Danışma Ve Rehberlik Dergisi, 9, 33-34.

Yıldırım, İ. (2006), Akademik Başarının Yordayıcısı Olarak Gündelik Sıkıntılar Ve Sosyal Destek, Hacettepe Üniversitesi Ë̆itim Fakültesi Dergisi, 30, 258- 267.

Zhang, M., Ve Lv, J. -M. (2011). A Research On İnfluencing Factors Of Adolescent Emotional Resilience. Psychological Science, 34(3), 593-597.

Zimet, G. D., Dahlem, N. W., Zimet, S. G., And Farley, G. K. (1988). The Multidimensional Scale Of Perceived Social Support. Journal Of Personality Assessment, 52(1), 30-41. 